\title{
Global Inequalities and Extractive Knowledge Production in the Bioeconomy
}

\author{
Maria Backhouse
}

\subsection{Introduction}

National and supra-national bioeconomy strategies are primarily geared towards research promotion and funding. The common goal is to create a new, knowledge-based growth market that will mitigate the ecological crises, such as climate change, through technological means (Backhouse et al. 2017). Technological innovation, in this perspective, is the engine of the aspired transition from a fossil-based society to one based on biomass. Depending on the respective supra-national or national context, different technological domains take centre stage in strategy papers-from biotechnologies to the efficient cascading use of renewable biomass (ibid.; Kleinschmit et al. 2014). All bioeconomy strategies essentially rest on the belief that economic growth can be decoupled from excessive resource depletion through the production of knowledge and (bio-)technological innovation.

\section{Backhouse $(\varangle)$}

Institute of Sociology, Friedrich Schiller University, Jena, Germany e-mail: maria.backhouse@uni-jena.de 
This technology optimism, however, is problematic, as it fails to recognise that knowledge and technologies are by no means ahistorical, neutral or objective, but instead are socio-historically and locally embedded (Haraway 1988). Moreover, the scientific descriptions of the ecological crisis and the political and technology-based strategies to solve it are permeated by global relations of power and social inequalities that have evolved alongside the emergence of colonialism and capitalism. In this chapter, I seek to demonstrate that existing bioeconomy strategies reproduce the global social inequalities inherent in the production of knowledge. Proceeding from approaches inspired by world systems theory (WST) as well as post- and decolonial studies, I conceive of the global inequality in knowledge production not only as an expression of the unequal production of and access to technological research and development $(\mathrm{R} \& \mathrm{D})$ on a global scale; rather, I seek to carve out the problematic notion of knowledge itself, as knowledge is inextricably linked to socio-ecological relations of power and inequalities. When I use the term "extractive knowledge" in this context, I am referring to R\&D undertaken on behalf of agro-industrial resource extraction in (semi-) peripheral countries that is for the most part intended for export. As I explain below, this form of knowledge production has been part and parcel of socio-ecological inequality since colonial times. ${ }^{1}$

In the following, I begin by reconstructing the critical debate around the bioeconomy in the social sciences and demonstrate that the research standpoint proceeding from global inequality has so far been underrepresented in critiques of this new form of ecological modernisation. In Sect. 2.2, I outline my research perspective on global inequalities in knowledge production. Subsequently, I use the policy strategies put forward by the OECD, EU, Germany and Brazil to illustrate how the relations of inequality emanating from these papers are perpetuated. In Sect. 2.4, I draw on the case of Brazil to flesh out the socioecological implications that arise from the strengthening of extractive knowledge production and the simultaneous marginalisation of alternative knowledge and technologies. Although Brazil has yet to formulate

\footnotetext{
${ }^{1}$ By using the term 'socio-ecological', I emphasise the dialectical connection between nature and society. On this, see Görg (2004) and the Introduction to this volume.
} 
a bioeconomy strategy, it is considered an important player in international bioeconomy forums. The country is one of the largest producers worldwide not only of biomass, but also of knowledge about genetically modified crops, the intensification of agro-industrial agriculture and the use of soybean and sugarcane for bioenergy. To conclude, I discuss the implications for the debate on a reorientation of the bioeconomy and the need for further research.

\subsection{Bioeconomy and the Critique of This New Form of Ecological Modernisation}

The bioeconomy is part of the green economy ${ }^{2}$ and rests on the notion of ecological modernisation (Kleinschmit et al. 2014, p. 403). Proponents of ecological modernisation believe that economic growth can be decoupled from climate change or the overexploitation of natural resources. The preconditions for such a decoupling include, firstly, market-based ecological policies that set the right incentives for the private sector and consumers. A second central requirement is the funding of technological innovation aimed at facilitating a more efficient and environmentally friendly use of resources (Bemmann et al. 2014, p. 12; Mol et al. 2014). This notion of innovation is based on a specific understanding of knowledge and development. "Knowledge" does not refer to knowledge per se, but rather to that which is produced primarily by researchers in the natural sciences and eventually translated into innovations as part of a seemingly linear path of development. In the prevailing bioeconomic concept, innovation denotes the successful commercialisation of knowledge in the form of new products and services (Birch 2017, pp. 3-4). Given this technology-oriented development optimism, policymakers see no contradiction in the fact that current bioeconomy strategies also stipulate funding for $\mathrm{R} \& \mathrm{D}$ in conventional agriculture, even though it is

\footnotetext{
${ }^{2}$ The green economy was adopted as the guiding principle at the 2nd UN Summit on Sustainable Development Rio +20 in Rio de Janeiro in 2012. The fields of action go beyond the bioeconomy to include all technologies and political frameworks that contribute to the conservation of resources, sustainable consumption and mobility systems.
} 
responsible for up to 30\% of climate-damaging emissions (IPCC-Intergovernmental Panel on Climate Change 2019). Their aim is to render the agricultural regime more environmentally friendly and to make it climate neutral through the use of technologies aimed at increasing efficiency. At the same time, new sustainable fields of accumulation are to emerge as a result of the valorisation of technological innovation (particularly via patents) (Birch et al. 2010). Instead of recognising the "limits to growth", the aim is the "growth of the limits" (Escobar 1996, p. 330).

Countless articles criticise this orientation of the bioeconomy. At the heart of this critique is the technology optimism inherent to bioeconomy strategies, which result in government research funding benefiting primarily mainstream areas of (bio-)technology and agricultural research. One major problem is that the EU's policymakers reduce the ecological crisis to technological inefficiency (Birch et al. 2010). However, instead of eliminating socio-ecological problems, the numerous technological innovations that have been implemented over the past few decades with the aim of increasing the efficiency of agroindustrial and monocultural production in the agricultural sector have partly aggravated them (TNI and Hands on the Land 2015). Today, the globalised agro-industrial sector has negative impacts on working conditions as well as land access and land use for smallholders in production regions worldwide. ${ }^{3}$ The growing demand for biomass in the context of bioeconomic policy (Bringezu et al. 2020; see also Lühmann in this volume) threatens to further entrench these social relations and exacerbate the ecological crisis, such as through the excessive consumption of freshwater and the emission of climate-damaging gases as a result of land use conversion or the growing use of fertilisers and agro-toxins (Fatheuer 2019; Moreno 2017). Adding to this is the increasing competition over the actual use of biomass either for food, energy or biochemical processing (ibid.).

Many critics, therefore, consider genuine socio-ecological and just solutions to be inconceivable within the dominant agricultural regime. They instead point to agroecology as an alternative approach to agricultural knowledge production (TNI and Hands on the Land 2015), which,

\footnotetext{
${ }^{3}$ See the articles by Lorenzen, Puder, Sinaga as well as Toledo-López in this volume.
} 
if at all, has only ever been discussed on the margins or promoted in the context of bioeconomy strategies (Bugge et al. 2016; Diedrich et al. 2011; Levidow et al. 2012; Schmid et al. 2012). The public debates demanded by many critics about orienting research funding towards a socio-ecologically just bioeconomy, however, have yet to materialise (see Lehmann in this volume).

I broaden this critical perspective by including a global perspective on unequal knowledge production. After all, most studies on bioeconomic technology and knowledge production are regionally focused on Europe and North America.

\subsection{Critical Perspectives on Unequal Global Knowledge Production}

In order to develop a research perspective that proceeds from unequal global knowledge production, I propose a stronger focus on the notion of development that is inherent in the modernisation narrative, and which has been criticised by approaches rooted in WST and post- and decolonial theory. After all, ecological modernisation amounts to the continuation of the classical doctrine of modernisation (Bemmann et al. 2014), according to which, Western Europe and North America represent the role models of all societies throughout the world. From this perspective, the European notions of rationalism, science and technological progress are considered "the jewels in the crown of modernity" (Harding 2011, p. 2). Negative socio-ecological impacts of technological developments are said to have emerged as a result of the improper and inefficient application of technologies (ibid., p. 5). The Eurocentric understanding of science is based on the dichotomous dissociation from the "rest of the world" that is commonly denigrated as traditional (vs. modern), underdeveloped (vs. developed) and irrational (vs. rational) (Hall 1992). By divorcing science and technologies from their socio-historical embeddedness and universalising them, the modernisation narrative not only conceals the producedness of knowledge, but also renders the global relations of power and social inequalities, which permeate this knowledge, invisible and naturalises them (Harding 2011). 
In the eyes of the proponents of ecological modernisation, it is therefore no contradiction that the old capitalist centres regard themselves as the trailblazers of environmental and climate protection.

Some important points of departure for my research are provided by studies from the WST research field. This analytical perspective (Wallerstein 2007) emphasises the significance of colonialism for the emergence of capitalism and focuses on the global inequalities that developed as a result. The unit of investigation encompasses the entire world system in which nation states are integrated according to a particular division of labour and global hierarchy as a consequence of colonialism. As centres, peripheries and semi-peripheries, they assume distinct positions within the relations of exchange in the world market. This historical perspective helps explain the relatively stable global hierarchies among nation states as well as the changes in their respective positions (e.g. China).

One important extension of WST is the research into unequal ecological exchange, which sheds light on how the global division of labour has been linked to the unequal extraction of resources and the distribution of environmental risks ever since colonial times (Bunker 1984; Gellert 2019). ${ }^{4}$ Consequently, the major economic growth in the capitalist centres to this day would be inconceivable without the resource influx from the (semi-)periphery; at the same time, the (semi-)periphery acts as a sink for the outsourcing of environmentally harmful production (Lipke 2011, p. 351). These global socio-ecological inequalities are linked to asymmetrical political power: the proposed solutions for dealing with the ecological crisis continue to be dominated by the ideas of North American and Western European institutions (ibid.).

These power asymmetries are also interlinked with unequal scientific and technological knowledge production on a global scale. Another extension of WST are studies on the unequal global production of knowledge, science and technology as generated and dominated by the Western centres since colonial times (Demeter 2019). Although the main centres of scientific and technological knowledge production shifted from Western Europe to North America over the course of the twentieth

${ }^{4}$ On this, see Lühmann in this volume. 
century, while East Asia became a more central region, the Latin American, Asian and African world regions have remained (semi-)peripheral (Schott 1998). This unequal global knowledge production is reproduced and, in part, even exacerbated, by the present-day political economy of science and academia (Demeter 2019). Empirical studies on global relations between centre, semi-periphery and periphery from the global natural sciences (Schott 1998), social sciences (Demeter 2019) and agricultural sciences (Delvenne and Kreimer 2017) consistently show the same tendency, albeit to varying degrees: despite the growing importance of China and other emerging countries in certain specialist fields (e.g. nanotechnology in China, biotechnologies in South Korea, or genetically modified crops in Brazil), the most influential journals as well as most publications and patents continue to come from the United States and Western Europe. Likewise, transnational research networks also reproduce these global inequalities in knowledge production, as a study of the EU research funding programme HORIZON suggests (Delvenne and Kreimer 2017, p. 394). According to the study's findings, these transnational research networks are for the most part headed by researchers and research institutions from the Western European and North American centres, whereas researchers from the (semi-)peripheries act as assistants and their share in theory formation only amounts to about $10 \%$ (ibid.). That said, global inequalities in knowledge production are not only perpetuated between countries, but also within countries. After all, whether they are in the centres or the peripheries, the only individuals who can successfully participate in "global" (or, more precisely, Anglo-American) science and academia are those who have gained the required professional experience abroad, the language skills they need, and whose class background provides them access to international networks (Demeter 2019).

The analytical perspectives on the unequal global production of knowledge as adopted by WST are conducive to comprehending the political economy of today's academic-scientific framework and the related global inequalities in knowledge production between and within countries. In the corresponding approaches, however, technological knowledge production itself does not take centre stage, as would be the case in research from a post- or decolonial perspective (Harding 2011; 
Graddy-Lovelace 2016). In these perspectives, agro-industrial knowledge production, in the form that appeared at the latest with the emergence of the Green Revolution during the 1970s, is a modernisation project that started in the US and has come to dominate worldwide agriculture due to the work of international development organisations, and that is inextricably linked to continuing colonial power asymmetries and hierarchies (Harding 2011). Proceeding from approaches that focus on unequal ecological exchange, I thus propose referring to "extractive knowledge" in this context. I view extractive knowledge as agro-technological knowledge that allows for and reproduces unequal resource extractivism ${ }^{5}$ as is manifest in globalised agriculture, in addition to all of the negative socio-ecological impacts and inequalities that are associated with it in production regions. This extractive knowledge, as a component of the agro-industrial sector, lies at the heart of the criticism of the orientation of research funding for bioeconomy strategies (see above). Despite the ascertained global social inequalities and power asymmetries, I conceptualise extractive knowledge not as monolithic, but as socially produced, historically situated and generally contested. After all, agro-industrial technologies are being challenged by agroecologists, social movements and NGOs worldwide.

Against this backdrop, I explore the following questions in a global context: Which and whose knowledge is to be funded in the context of the bioeconomy? Are global inequalities in extractive knowledge production challenged or reproduced? I answer these questions in two steps: first, I examine the bioeconomy strategy papers put forward by the EU, Germany, the OECD and Brazil. In a second step, I focus on Brazil's research funding in the agricultural sector, using the example of soybean.

${ }^{5}$ The term extractivism originally only referred to mining, but is now also used in the context of agriculture. For more details, see Tittor in this volume. 


\subsection{The Continued Global Division of Labour in Knowledge Production}

An analysis of the bioeconomy strategy papers put forward by the OECD, the EU and Germany illustrate that they reproduce the inequalities in global knowledge production outlined above. This is evidenced by the fact that the new narrative of the bioeconomy as a green, marketbased vision of the future was originally conceptualised by the OECD and is being substantively shaped and globally disseminated above all by the capitalist centres-especially the EU (Backhouse et al. 2017). As a result, the global policy for mitigating the ecological crisis-including with regard to the bioeconomy-is once again being defined by the capitalist centres.

In addition, these visions of a bioeconomy reproduce the global division of labour in technological knowledge production. The OECD and the EU locate the technology centres of this knowledge-based bioeconomy primarily in North America and Western Europe (OECD 2009; European Commission 2012, 2018). Similar to the EU as a whole (European Commission 2018, p. 4), Germany also emphasises its "global responsibility" (BMBF and $\mathrm{BMEL}^{6}$ 2020, p. 4) as well as the need to initiate global research collaborations in order to generate synergies through an exchange of knowledge (ibid., pp. 33-34). This notion rests on the conviction that "each country and region can make an individual contribution to the global bioeconomy through its own mix of raw materials, technologies, knowledge and ideas" (ibid., p. 34). However, both papers are dominated by a competition-oriented perspective: it is all about maintaining and enhancing "its global leadership" in the development and marketisation of (bio-)technologies (European Commission 2018, p. 6; BMBF and BMEL 2020, p. 4). Correspondingly, the specified objectives do not foresee (semi-)peripheral countries rising above their role as raw material suppliers within the global division of labour. However, the OECD paper does consider changes in unequal globalised

\footnotetext{
${ }^{6}$ Federal Ministry of Education and Research (BMBF) and Federal Ministry of Food and Agriculture (BMEL).
} 
knowledge production to be feasible and even describes them as a desirable outcome (OECD 2009, p. 198). Countries such as India, Brazil and especially China are viewed as having research capacities that are or could become relevant for the bioeconomy (ibid.). And yet, these papers do not address the unequal global distribution of the "high technological fields" (Delvenne and Kreimer 2017, p. 391) in the centres, and less complex technology domains in the (semi-)peripheries.

This modernisation narrative is being adopted by powerful players in industry, agriculture and politics in Brazil. According to the Brazilian Ministry of Science, Technology and Communications (MCTIC), the objective is to secure Brazil's leading role in the global competition for new technologies and markets by promoting and funding a higher degree of professional qualification and the expansion of its own biotechnological research in the fields of medicine, biotechnological industries and agriculture via government funding and public-private partnerships (MCTIC 2016). In this sense, a sub-chapter of the Brazilian research strategy demonstrates that Brazil's approach to the bioeconomy is similar to the approach put forward by the OECD in its 2009 strategy paper (see OECD 2009), namely in relation to the generation of biotechnological knowledge (MCTIC 2016, p. 96). In the global competition over pioneering biotechnology in the knowledge-based bioeconomy, Brazil believes its "comparative advantage" vis-à-vis other countries is the great wealth of biodiversity found in Brazil and the leading role the country plays in agribusiness ${ }^{7}$ and biofuels (ibid., p. 96, own translation). A similar argument is put forward by the Brazilian National Confederation of Industry (CNI), which advocates a national bioeconomy strategy for Brazil and sets out the corresponding objectives and fields of action in its own papers (CNI 2014; Harvard Business Review 2013). In this case, sustainability and the reduction of $\mathrm{CO}_{2}$ emissions in agriculture are to be achieved through biotechnological innovation (e.g. genetic modified organisms, synthetic biology) in the fields of bioenergy (sugarcane- and corn-based ethanol; soy-based biodiesel) and agriculture (e.g. new plant varieties such as eucalyptus, soy and corn) (Harvard Business Review 2013, pp. 19-20). The development goal-apart from exporting raw

${ }^{7}$ On the adoption of the US concept of agribusiness in Brazil, see Pompeia (2020). 
materials - is the manufacture of high-quality and innovative products for the international market (ibid.).

The extent to which Brazil will actually manage to overcome global unequal knowledge production remains to be seen. Even if the research strategy of the former centre-left government of Dilma Rousseff is officially continued (MCTIC 2016; Mourão 2020), research policy has changed profoundly since radical right-wing President Jair Messias Bolsonaro took office in 2019. Universities and research centres in Brazil have suffered massive funding cuts. ${ }^{8}$ As I demonstrate in the following section, the Brazilian adoption of the bioeconomy fosters a type of knowledge production that has been driving resource extraction since the Green Revolution of the 1970s_-regardless of whether the respective (bio-)technologies have been imported or homegrown.

\subsection{Extractive Knowledge Production in Brazil}

As semi-peripheral country, ${ }^{9}$ Brazil is by no means a mere recipient of agricultural technology from the North American and Western European knowledge centres. Brazil has ranked as the country with the largest agricultural research sector in Latin America since the year 2000 both in terms of research funding and the number of researchers with a $\mathrm{PhD}$ in this field (ASTI ${ }^{10}$ 2016; IAASTD ${ }^{11}$ 2009). According to a World Bank study from 2014, the Brazilian government invested about $1 \%$ of its GDP in agricultural research (by comparison: the US invested $1.4 \%$ of its GDP in the same year; see Correa and Schmidt 2014). A substantial share of these funds went to the Brazilian Agricultural Research Corporation (EMBRAPA) (ibid.), on which I focus in the following section.

\footnotetext{
${ }^{8}$ Public funding for science and technology was reduced from 6.37 billion reais in 2019 to 2.91 reais in 2020. See, http://www.portaltransparencia.gov.br/funcoes/19-ciencia-e-tecnologia? ano=2018. Accessed 20 Aug 2020 .

${ }^{9}$ On the definition of semi-peripheral countries, see Delvenne and Kreimer (2017, p. 391).

${ }^{10}$ ASTI-Agricultural Science and Technology Indicators.

${ }^{11}$ IAASTD-International Assessment of Agricultural Knowledge, Science and Technology for Development.
} 
Although EMBRAPA has recently suffered a loss to its erstwhile influence, ${ }^{12}$ since its inception during the military dictatorship in the 1970 s, the institute has significantly contributed to orientating the Brazilian agricultural sector towards the US model (Mengel 2015). As I would like to briefly outline using the example of soybean, this research orientation is an expression of extractive knowledge production that results in the use of new technological means to reproduce the unequal ecological exchange between the regions in Brazil that cultivate soybean and the recipient regions in Europe and China, and the Brazilian centres.

Alongside market liberalisation and expired patents, which reduced the price of agro-industrial inputs (herbicides, pesticides, fertilisers, machinery, etc.), as of the 1990s, it was the EMBRAPA's development departments that significantly contributed to the proliferation of soybean production in the savannah of Cerrado and the Amazon region, areas previously deemed inadequate for farming due to poor soil quality or climatic conditions. In order to do so, they promoted the use of genetically modified crops, improved farming methods such as no-till farming, and agrochemicals (Correa and Schmidt 2014).

Today, soy farming covers vast areas: the US Department of Agriculture (USDA) estimates that the soybean harvest in 2020/2021, which encompasses 38.5 million hectares (ha) of land (for comparison: the total area of Germany is 35.7 million ha), will yield 129 million metric tons ( $\mathrm{t}$ ) (USDA 2020). Brazil is thus not only the biggest producer of soybean in the world, but also the second-largest producer of "biotech crops", which includes genetically modified soybean, corn and cotton (ibid.). Some $96 \%$ of soybean produced in Brazil is genetically modified. In 2019 alone, applications for the commercial cultivation of 107 genetically modified crops were submitted in Brazil, 19 of which were varieties of soybean (ibid.). Exports of soybean are forecast at 79 million t for 2020/2021. China is the largest importer of Brazilian soybean (up to $75 \%$ of the Brazilian crop), followed by Europe (USDA 2019). ${ }^{13}$

\footnotetext{
${ }^{12}$ Under the Bolsonaro administration, funding for EMBRAPA was cut from 3.35 billion reais in 2019 to 1.75 billion reais in 2020. See, http://www.portaltransparencia.gov.br/orgaos/22202? ano=2020. Accessed 20 Aug 2020 .

${ }^{13}$ On the restructuring of global inequalities and South-South relations, see Rodríguez in this volume.
} 
The sector was additionally bolstered by the introduction of biodiesel in Brazil in 2004. Biodiesel consists of about $70 \%$ soybean oil, a waste product from the animal feed industry (USDA 2020). Since 2019, the blending quota has been at $11 \%$ and was raised to $12 \%$ in March 2020 (ibid.). However, corn-based ${ }^{14}$ ethanol production (blending quota: $27 \%$ ) is becoming increasingly appealing for the sector in soybean expansion regions, given that corn can be cultivated in crop rotation after harvesting soy (USDA 2019). Furthermore, the waste from corn ethanol production can be used as animal feed, which encourages the expansion of grazing pastures for cattle in the major growing regions located, in among other areas, in the Amazon region. Corn ethanol may thus "become a crucial connecting link in a new agro-industrial complex comprised of a combination of soybean, corn, ethanol and livestock farming" (Fatheuer 2019, p. 15; own translation), which could, in turn, reinforce and accelerate the dynamics of deforestation. Thus, technological innovations like crop rotation and cascade use of biomass alone are no guarantee of sustainable development.

The relationship between this form of knowledge production and socio-ecological inequalities in the Brazilian agricultural sector is evident when we consider the question of land access: the unprecedented expansion of soybean cultivation over the past 50 years has been made possible not only through technological innovation, but also because land access is controlled by a small elite in concert with major political actors. The massive concentration of land access has its origins in colonial times and represents one of the main historical reasons for Brazil's striking social inequalities. The expansion of soybean cultivation exacerbates these socio-ecological inequalities: the Federal State of Mato Grosso is one of the main growing regions, and around $80 \%$ of its farmland is owned by large landowners who own more than 1000 ha. ${ }^{15}$ Soybean cultivation and the corresponding infrastructure (roads, ports) have become one of the main drivers of deforestation and the displacement of indigenous

\footnotetext{
${ }^{14}$ This is a new development. Until now, Brazilian ethanol has been based almost exclusively on sugarcane, see Backhouse (2020).

${ }^{15}$ Own calculation based on the 2017 agricultural census, see, https://sidra.ibge.gov.br. Accessed 20 Oct 2020.
} 
people and (traditional) smallholders in the Amazon region today (Torres and Branford 2018).

Brazil's specialised knowledge production, therefore, not only limits agricultural research to the needs of agribusiness but, for decades, has also contributed to a fundamental restructuring of the Brazilian agricultural sector.

Furthermore, government programmes such as "Low-Carbon Emissions Agriculture" (Agricultura de Baixa Emissão de Carbono), which promotes technical efficiency increases via research funding for ecological modernisation, have also had no impact on the socio-ecological effects of soybean cultivation (Assad 2013). Technological innovations like precision agriculture, no-till farming, yield increases through new varieties, or rotating corn and soybean cultivation have failed to limit the socio-ecologically problematic expansion of cultivation areas. Instead, extractive knowledge production has been merely re-framed as part of ecological modernisation.

Alternative agroecological or traditional forms of agriculture, which are not incorporated into agribusiness (e.g. by contract farming), are not only displaced spatially, but also marginalised in terms of knowledge production. The major imbalances in the relations of power and social inequalities, as manifested spatially in the high degree of land ownership concentration in the hands of a small elite and politically in the influence of the agricultural lobby in parliament (bancada ruralista), also extend into the area of R\&D. At the same time, this specialisation in knowledge production reinforces extraction relations due to the export orientation of the entire soybean sector (Backhouse and Lühmann 2020). Brazil's "individual contribution" to the global bioeconomy is thus associated with major socio-ecological problems at the local level with regard to both raw materials and knowledge.

Of course, the exclusion of alternative forms of knowledge in the agricultural sector does not mean that they do not exist or do not matter at all. The landless movement MST (Movimento dos Trabalhadores Rurais sem Terra) and other social movements have advocated agroecology and food sovereignty for many years. In the process, they have established their own knowledge centres such as the MST education centre Escola Nacional Florestan Fernandes and the agricultural engineering 
institute for land reform research Iterra (Instituto Técnico de Pesquisa e Reforma Agrária) in São Paulo. So far, these civil society actors have not participated in the (inter-)national bioeconomy forums and are, correspondingly, excluded from negotiations on the orientation of bioeconomy strategies.

\subsection{Conclusion}

As shown in this chapter, today's bioeconomy reproduces the existing global socio-ecological inequalities in the area of knowledge production. The technological leadership role of North America and Western Europe is already expressed in the corresponding policy papers. The (semi-)periphery participates in the bioeconomy through its respective fields of specialisation and expertise.

As previous critical analyses of these policy strategies have shown, and the case of Brazil underscores, the ecological modernisation narrative associated with the bioeconomy in agriculture is dominated primarily by the agro-industrial sector. There is a great danger that this research funding orientation will deepen the extractive relations between countries that export raw materials and those that consume them-at the same time, exacerbating the socio-ecological crisis. Research is still needed into the question of whether the current changes in research funding under the Bolsonaro administration are exacerbating these dynamics.

The case of Brazilian soybean underlines the point that improved technologies may provide yield increases, but this will not necessarily stop the expansion dynamics associated with a particular crop. A decrease in biodiversity and unequal relations of access to and use of land can even be compounded as a result. Any meaningful socio-ecological solution within this agro-industrial agricultural regime can thus be ruled out. This makes it all the more important to develop alternative visions to this extractive knowledge. The great challenge that remains for critical actors in academia and science as well as in civil society, therefore, is to re-politicise and democratise not only the field of debate surrounding the bioeconomy, but technological knowledge production and government research funding as a whole. This is the only way to help initiate 
social negotiation processes that would further the development of alternative bioeconomies in highly distinct contexts and countries. Starting points for democratic fields of experimentation of alternative knowledge production that merit public funding, including social movements for agroecology and food sovereignty, can be found worldwide.

\section{References}

Assad, E.D. (2013). Agricultura de Baixa Emissão de Carbono: A evolução de um novo paradigma. São Paulo: Fundação Getulio Vargas; Centro de Agronegócio, Escola de Economia de São Paulo.

ASTI (2016). Agricultural R\&D Indicators Factsheet: Brazil. Key indicators. https://www.asti.cgiar.org/pdf/factsheets/Brazil-Factsheet.pdf. Accessed 20 Aug 2020.

Backhouse, M. (2020). The Knowledge-Based Bioeconomy in the SemiPeriphery: A Case Study on Second-Generation Ethanol in Brazil. Working Paper 13, Bioeconomy \& Inequalities, Jena. https://www.bioinequalities.unijena.de/sozbemedia/wp/workingpaper13.pdf. Accessed 20 Aug 2020.

Backhouse, M., Lorenzen, K., Lühmann, M., Puder, J., Rodríguez, F., \& Tittor, A. (2017). Bioökonomie-Strategien im Vergleich: Gemeinsamkeiten, Widersprüche und Leerstellen. Working Paper 1, Bioeconomy \& Inequalities, Jena. https://www.bioinequalities.uni-jena.de/sozbemedia/neu/2017-09-28+ workingpaper+1.pdf. Accessed 17 Dec 2018.

Backhouse, M., \& Lühmann, M. (2020). Stoffströme und Wissensproduktion in der globalen Bioökonomie: Die Fortsetzung globaler Ungleichheiten. Peripherie 159/160, 235-257.

Bemmann, M., Metzger, B., \& von Detten, R. (2014). Einleitung. In B. Metzger, M. Bemmann \& R. von Detten (Eds.), Ökologische Modernisierung: Zur Geschichte und Gegenwart eines Konzepts in Umweltpolitik und Sozialwissenschaften (pp. 7-32). Frankfurt: Campus Verlag.

Birch, K. (2017). Innovation, Regional Development and the Life Science: Beyond Clusters (Regions and cities, 105). London, New York: Routledge Taylor \& Francis Group.

Birch, K., Levidow, L., \& Papaioannou, T. (2010). Sustainable Capital? The Neoliberalization of Nature and Knowledge in the European "Knowledgebased Bio-economy”. Sustainability, 2, 2898-2918. 
BMBF \& BMEL (2020). National Bioeconomy Strategy. Berlin. https://biooek onomie.de/sites/default/files/bmbf_national-bioeconomy-strategy_en_0.pdf. Accessed 19 Oct 2020.

Bringezu, S., Banse, M., Ahmann, L., Bezama, A., Billig, E., Bischof, R., et al. (2020). Pilotbericht zum Monitoring der deutschen Bioökonomie. Kassel University, Center for Environmental Systems Research (CESR). https:// kobra.uni-kassel.de/handle/123456789/11591. Accessed 28 Sep 2020.

Bugge, M., Hansen, T., \& Klitkou, A. (2016). What Is the Bioeconomy? A Review of the Literature. Sustainability, 8, 691.

Bunker, S.G. (1984). Modes of Extraction, Unequal Exchange, and the Progressive Underdevelopment of an Extreme Periphery: The Brazilian Amazon, 1600-1980. American Journal of Sociology, 89(5), 1017-1064.

CNI (2014). Bioeconomia: oportunidades, obstáculos e agenda: Mapa Estratégico da Indústria 2013-2022. Uma agenda para a competitividade. Brasília. http://arquivos.portaldaindustria.com.br/app/conteudo_24/2014/ 07/22/479/V35_Bioeconomiaoportuidadesobstaculoseagenda_web.pdf. Accessed 27 Aug 2020.

Correa, P., \& Schmidt, C. (2014). Public Research Organizations and Agricultural Development in Brazil: How Did Embrapa Get It Right? Economic Premise, 145. The World Bank, 1-10. http://documents1.worldbank.org/ curated/en/156191468236982040/pdf/884900BRI0EP1450Box385225B0 00PUBLIC0.pdf. Accessed 9 March 2020.

Delvenne, P., \& Kreimer, P. (2017). World-System Analysis 2.0: Globalized Science in Centers and Peripheries. In D. Tyfield, C. Thorpe, R. Lave \& S. Randalls (Eds.), The Routledge Handbook of the Political Economy of Science (pp. 390-404). London: Taylor \& Francis.

Demeter, M. (2019). The World-Systemic Dynamics of Knowledge Production: The Distribution of Transnational Academic Capital in the Social Sciences. Journal of World-Systems Research, 25, 111-144.

Diedrich, A., Upham, P., Levidow, L., \& van den Hove, S. (2011). Framing Environmental Sustainability Challenges for Research and Innovation in European Policy Agendas. Environmental Science \& Policy, 14, 935-939.

Escobar, A. (1996). ConstructionNature: Elements for a Post-Structuralist Political Ecology. Futures, 28(4), 325-343.

European Commission (2012). Innovation for Sustainable Growth: A Bioeconomy for Europe: Communication from the Commission to the European Parliament, the Council, The European Economic and Social Committee and the Committee of the Regions. Brussels. http://ec.europa.eu/research/bioeco nomy/pdf/official-strategy_en.pdf. Accessed 5 June 2015. 
European Commission (2018). A Sustainable Bioeconomy for Europe: Strengthening the Connection Between Economy, Society and the Environment. Brussels. https://ec.europa.eu/research/bioeconomy/pdf/ec_bioeco nomy_strategy_2018.pdf. Accessed 17 May 2020.

Fatheuer, T. (2019). Zuckerträume: Ethanol aus Brasilien in der globalen Klimapolitik. FDCL. Berlin. https://www.fdcl.org/wp-content/uploads/ 2020/03/FDCL_Zuckertra\%CC\%88ume_web.pdf. Accessed 23 June 2020. Gellert, P.K. (2019). Bunker's Ecologically Unequal Exchange, Foster's Metabolic Rift, and Moore's World-Ecology: Distinctions With or Without a Difference? In R.S. Frey, P.K. Gellert \& H.F. Dahms (Eds.), Ecologically Unequal Exchange (pp. 107-140). Cham: Palgrave Macmillan.

Görg, C. (2004). The Construction of Societal Relationships with Nature. Poiesis \& Praxis, 3(1), 22-36.

Graddy-Lovelace, G. (2016). The Coloniality of US Agricultural Policy: Articulating Agrarian (In)Justice. Journal of Peasant Studies, 44(1), 78-99.

Hall, S. (1992). The West and the Rest: Discourse and Power. In S. Hall \& B. Gieben (Eds.), Formations of Modernity (pp. 185-227). Cambridge: Polity Press in association with Blackwell and the Open University.

Haraway, D. (1988). Situated Knowledges: The Science Question in Feminism and the Privilege of Partial Perspective. Feminist Studies, 14(3), 575-599.

Harding, S.G. (2011). Introduction: Beyond Postcolonial Theory: Two Undertheorized Perspectives on Science and Technology. In S.G. Harding (Ed.), The Postcolonial Science and Technology Studies Reader (pp. 1-31). Durham: Duke University Press.

Harvard Business Review (2013). Bioeconomy: An Agenda for Brazil. http:// arquivos.portaldaindustria.com.br/app/conteudo_24/2013/10/18/411/201 31018135824537392 u.pdf. Accessed 19 Sep 2017.

IAASTD (2009). Agriculture at a Crossroad: International Assessment of Agricultural Knowledge, Science and Technology for Development. Synthesis Report. Washington, D.C. https:/www.weltagrarbericht.de/fileadmin/files/ weltagrarbericht/IAASTDBerichte/SynthesisReport.pdf. Accessed 19 June 2020.

IPCC (2019). IPCC Special Report on Climate Change, Desertification, Land Degradation, Sustainable Land Management, Food Security, and Greenhouse Gas Fluxes in Terrestrial Ecosystems: Summary for Policymakers Approved Draft. https://www.ipcc.ch/site/assets/uploads/2019/08/ Edited-SPM_Approved_Microsite_FINAL.pdf. Accessed 7 April 2020. 
Kleinschmit, D., Lindstad, B.H., Thorsen, B.J., Toppinen, A., Roos, A., \& Baardsen, S. (2014). Shades of Green: A Social Scientific View on Bioeconomy in the Forest Sector. Scandinavian Journal of Forest Research, 29, 402-410.

Levidow, L., Birch, K., \& Papaioannou, T. (2012). Divergent Paradigms of European Agro-Food Innovation: The Knowledge-Based Bio-Economy (KBBE) as an R\&D Agenda. Science, Technology, \& Human Values, 38(1), $94-125$.

Lipke, J. (2011). Globale Herrschaftsverhältnisse und Naturaneignung: Eine weltsystemische und sozial-ökologische Betrachtung der globalen Umweltkrise. In T. Mayer, R. Meyer, L. Miliopoulos, P.H. Ohly \& E. Weede (Eds.), Globalisierung im Fokus von Politik, Wirtschaft, Gesellschaft: Eine Bestandsaufnahme (pp. 351-371). Wiesbaden: VS Verlag für Sozialwissenschaften.

MCTIC (2016). Estratégia Nacional de Ciência, Tecnologia e Inovação 2016-2022. Brasília. http://www.finep.gov.br/images/a-finep/Politica/16_ 03_2018_Estrategia_Nacional_de_Ciencia_Tecnologia_e_Inovacao_2016_ 2022.pdf. Accessed 23 Aug 2020.

Mengel, A.A. (2015). Modernização da agricultura e pesquisa no Brasil: a Empresa Brasileira de Pesquisa Agropecuária - EMBRAPA. PhD. Universidade Federal Rural do Rio de Janeiro, Rio de Janeiro.

Mol, A.P.J., Spaargaren, G., \& Sonnenfeld, D.A. (2014). Ecological Modernisation Theory: Where Do We Stand? In B. Metzger, M. Bemmann \& R. von Detten (Eds.), Ökologische Modernisierung: Zur Geschichte und Gegenwart eines Konzepts in Umweltpolitik und Sozialwissenschaften (pp. 35-66). Frankfurt: Campus Verlag.

Mourão, A.H.M. (2020): Amazônia: a Nova Fronteira da Bioeconomia. Interesse Nacional, 1, 9-13.

Moreno, C. (2017): Landscaping a Biofuture in Latin America. FDCL. Berlin. https://www.fdcl.org/wp-content/uploads/2017/07/FDCL_BIOEC_EN18 072017-2.pdf. Accessed 20 Aug 2020.

OECD (2009). The Bioeconomy to 2030: Designing a Policy Agenda. Paris. http://biotech2030.ru/wp-content/uploads/docs/int/The\%20Bioecon omy\%20to\%202030_OECD.pdf. Accessed 5 June 2020.

Pompeia, C. (2020). "Agro é tudo": simulaçôes no aparato de legitimação do agronegócio Horizontes Antropológicos, 26(56), 195-224.

Schmid, O., Padel, S., \& Levidow, L. (2012). The Bio-Economy Concept and Knowledge Base in a Public Goods and Farmer Perspective. Bio-based and Applied Economics, 1(1), 47-63. 
Schott, T. (1998). Ties between Center and Periphery in the Scientific WorldSystem: Accumulation of Rewards, Dominance and Self-Reliance in the Center. Journal of World-Systems Research, 4(2), 112-144.

TNI \& Hands on the Land (2015). The Bioeconomy. A Primer. https:// www.tni.org/files/publication-downloads/tni_primer_the_bioeconomy.pdf. Accessed 1 Sep 2018.

Torres, M., \& Branford, S. (2018). Amazon Besieged: By Dams, Soya, Agribusiness and Land-Grabbing. Warwickshire, UK: Practical Action Publishing. USDA (2019). Brazil: Oilseeds and Products Annual. GAIN Report (BR1906). https://apps.fas.usda.gov/newgainapi/api/report/downloadreportbyfilename? filename=Oilseeds\%20and $\% 20$ Products $\% 20$ Annual_Brasilia_Brazil_4-22019.pdf. Accessed 19 June 2020.

USDA (2020). Oilseeds and Products Annual: Brazil (BR2020-0011). https:// apps.fas.usda.gov/newgainapi/api/Report/DownloadReportByFileName?fil eName=Oilseeds\%20and\%20Products\%20Annual_Brasilia_Brazil_04-012020. Accessed 19 June 2020.

Wallerstein, I. (2007). World-Systems Analysis: An Introduction (5th ed., A John Hope Franklin Center book). Durham: Duke University Press.

Open Access This chapter is licensed under the terms of the Creative Commons Attribution 4.0 International License (http://creativecommons.org/ licenses/by/4.0/), which permits use, sharing, adaptation, distribution and reproduction in any medium or format, as long as you give appropriate credit to the original author(s) and the source, provide a link to the Creative Commons license and indicate if changes were made.

The images or other third party material in this chapter are included in the chapter's Creative Commons license, unless indicated otherwise in a credit line to the material. If material is not included in the chapter's Creative Commons license and your intended use is not permitted by statutory regulation or exceeds the permitted use, you will need to obtain permission directly from the copyright holder. 